\title{
OPTIMALISASI PELAYANAN PUBLIK DI BIDANG PERIZINAN
}

\author{
Dyah Adriantini Sintha Dewi \\ Fakultas Hukum Universitas Muhammadiyah Magelang \\ Jl. Tidar No. 21 Magelang \\ Email: dyahadriantini@yahoo.com
}

\begin{abstract}
The process to get a permit in public service's office usually need a long time. On the contrary, everyone has right to get good public service. The enactment of Law No. 25/2009 about the Public Service as the basis of public services officials, because basically bureaucrats are public servants. However, to realize a good public service, not only depend on a good rule but also moral executor. They contribute in the success of public services. In the fact, the existence of Integrated Service System model, can be a solution to optimize public services especially in licensing .
\end{abstract}

Keywords: Optimalization; Public Service; Licensing.

\begin{abstract}
Abstrak
Proses perolehan izin di kantor pelayanan publik biasanya membutuhkan waktu yang lama. Sebaliknya Pemberian layanan publik yang baik adalah hak dari setiap warga Negara. Diberlakukannya Undang-Undang Nomor 25 Tahun 2009 tentang Pelayanan Publik menjadi landasan bagi pelaksana layanan publik, karena pada dasarnya birokrat adalah pelayan masyarakat. Namun, untuk mewujudkan pelayanan yang baik, tidak hanya tergantung pada aturan yang baik saja melainkan juga moral pelaksana. Hal itu menentukan keberhasilan dalam pemberian layanan publik. Dalam praktik adanya model Sistem Pelayanan Terpadu, dapat menjadi solusi bagi upaya optimalisasi layanan publik, khususnya di bidang perizinan.
\end{abstract}

Kata kunci: Optimalisasi; Pelayanan Publik; Perizinan.

\section{A. Pendahuluan}

Dalam upaya mewujudkan tujuan negara sebagaimana diamanatkan dalam aline ke-empat pembukaan Undang-Undang Dasar 1945, yaitu "untuk memajukan kesejahteraan umum dan mencerdaskan kehidupan bangsa," maka pemerintah berkewajiban untuk memberikan layanan publik yang baik bagi seluruh rakyat. Pelayanan publik sebagai hak dari setiap warga Negara, juga tersirat dalam Pasal 44 Undang-Undang Nomor 39 Tahun 1999 tentang Hak Asasi Manusia, di mana setiap orang berhak mengajukan permohonan kepada pemerintah dalam rangka pelaksanaan pemerintahan yang bersih, efektif dan efisien, dapat dimaknai adanya hak warga negara untuk juga memperoleh pelayanan publik yang baik. Dengan demikian, terlihat bahwa adanya pelayanan publik yang baik adalah merupakan kewajiban dari pemerintah atas setiap warganya. Namun dalam kenyataannya masih banyak terjadi adanya layanan publik yang buruk (maladministrasi) ${ }^{1}$ yang menimbulkan kerugian pada masyarakat. Maladministrasi sebagai bentuk pelayanan publik yang buruk, meliputi beberapa kegiatan, yaitu: 1) penundaan berlarut, 2) tidak menangani, 3) persekongkolan, 4) pemalsuan, 5) di lur kompetensi, 6) tidak kompeten, 7) penyalahgunaan wewenang, 8) bertindak sewenang-wenang, 9) korupsi, 10) kolusi dan nepotisme, 11) penyimpangan prosedur, 12) melalaikan kewajiban, 13) bertindak tidak layak/ tidak patut, 14) penggelapan barang bukti, 15) penguasaan tanpa hak, 16) bertindak tidak adil, 17) intervensi, 18) nyata-nyata berpihak, 19)

\footnotetext{
1. Sunaryati Hartono, et all,2003, Panduan Investigasi untuk Ombudsman Indonesia, Jakarta, Komisi Ombudsman Nasional, hlm. 18-21.
} 
pelanggaran undang-undang, 20) perbuatan melawan hukum.

Ada beberapa judul dalam media yang cukup menggelitik berkait dengan pelayanan publik, antara lain: "Pelayanan Publik Belum Sesuai Harapan", 2 "Ombudsman: mayoritas Pelayanan Publik SKPD Pemkab Sergai Masuk Zona Merah", "Hanya BPMPPT dan bagian SM Berpotensi Zona Hijau". Sementara itu, dalam survey yang dilakukan oleh World Bank tahun 2011 terhadap 183 negara, pelayanan publik yang dilakukan oleh birokrasi Indonesia menemati urutan ke-129, dan atas survey yang dilakukan oleh Corruption Perception Index tahun 2012, dari 174 negara yang disurvey, Indonesia menempatiperingkat 118 dengan skor CPI $32 .{ }^{5}$ Di sini nampak, bahwa sekalipun sudah lahir Undang-Undang Nomor 25 Tahun 2009 tentang Pelayanan Publik, dalam praktek pelaksanaanya belum efektif mengingat masih banyak pelayanan publik yang buruk.

Pelayanan publik yang banyak mendapat sorotan dari masyarakat adalah berkait dengan masalah perizinan, mengingat prosesnya yang demikian panjang dan memakan waktu lama disamping pembiayaan yang tidak sedikit. Kondisi yang demikian biasa dikategorikan sebagai penyakit birokrasi red tape, yaitu berkaitan dengan penyelenggaraan pelayanan yang tidak efisien sekalipun sebenarnya dapat diselesaikan secara singkat. ${ }^{6} \mathrm{Hal}$ ini sebagai salah satu akibat belum adanya perubahan paradigma di lingkungan birokrat, di mana seharusnya para birokrat harus menjalankan fungsi pemerintahan yang salah satunya adalah fungsi pelayanan, yaitu untuk memberikan pelayanan yang baik.

Atas dasar uraian di atas maka penting untuk dikaji dalam tulisan ini tentang bagaimana proses perizinan yang selama ini masih banyak dikeluhkan oleh masyarakat? Analisis berangkat dari fakta empiris yang terjadi di masyarakat dan akan berujung pada diajukannya solusi melalui pendeskripsian bentuk pelayanan perizinan yang efisien dan membawa kebahagian bagi masyarakat.

\section{B. Pembahasan}

\section{Ruang Lingkup Pelayanan Publik}

Sebagaimana diuraikan dalam dalam Undang-Undang Nomor 25 Tahun 2009 tentang Pelayanan Publik, bahwa pelayanan publik sebagai upaya memberikan hak pada setiap warga negara, meliputi pelayanan bidang barang, jasa dan administratif. Berangkat dari hal tersebut, terlihat betapa luasnya ruang lingkup pengaturan berkait pelayanan publik. Disahkannya UndangUndang Nomor 25 Tahun 2009 tentang Pelayanan Publik dimaksudkan untuk memberikan kepastian hukum dalam hubungan antara masyarakat dan penyelenggara dalam pelayanan publik.

Dalam upaya memenuhi maksud tersebut, maka penyelenggaraan pelayanan publik sebagaimana diatur tercantum dalam Pasal 4, adalah berlandaskan pada asas-asas: a) kepentingan umum, b)kepastian hukum, c) kesamaan hak, d) keseimbangn hak dan kewajiban, e) keprofesionalan, f) partisipatif, g) persamaan perlakuan/ tidak diskriminatif, h)keterbukaan, I) akuntabilitas, j) fasilitas dan perlakuan khusus bagi kelompok rentan, k) ketepatan waktu, 1) kecepatan, kemudahan, dan keterjangkauan. Asas-asas tersebut sekaligus menjadi landasan bagi perwujudan layanan prima yang menjadi dambaan bagi setiap warga negara.

Keseluruhan ruang lingkup pelayanan publik perlu mendapat perhatian yang seimbang. Untuk pengadaan barang publik

2.Suara Merdeka, Sabtu 17 Oktober 2015, hlm. 28.

3. Kabar Medan.com, 9 Oktober 2015, "mayoritas Pelayanan Publik SKPD Pemkab Sergai Masuk Zona Merah" tersedia di website http://www.ombudsman.go.id/index.php/en/beritaartikel/berita/2171-ombudsma--mayoritas-pelayanapublik-skpd-pemkab-sergai-masuk-zona-merah.html, diakses pada tanggal 19 Oktober 2015.

4.Palopo Pos, 10 September 2015, "Hanya BPMPPT dan Bagian SIM Berpotensi Zona Hijau”, tersedia di website http://www.ombudsman.go.id/index.php/beritaartikel/berita/2079-hanya-bpmppt-dan-bagian-sim-berpotensi-zonahijau.html, diakses pada tanggal 19 Oktober 2015.

5. Ombudsman Republik Indonesia Bidang Pencegahan, 2013, "Kepatuhan Lembaga dalam Pelaksanaan UndangUndang 25 Tahun 2009 tentang Pelayanan Publik", tersedia di website http://koleksifotoombudsman.files.wordpress.com/20, diakses pada tanggal 19 Oktober 2015.

6. Hendra Nurtjahjo, Yustus Matrbongs, Diani Indah Rachmitasari, 2013, Memahami Maladministrasi, Jakarta, Ombudsman Republik Indonesia, hlm. 12. 
dan penyediaan jasa publik, meliputi baik yang pendanaannya dari pemerintah pusat mapun daerah. Sementara untuk tindakan administrasi pemerintah, sebagaimana diuraikan dalam Peraturan Pemerintah Nomor 96 Tahun 2012 tentang Pelaksanaan Undang-Undang Nomor 25 Tahun 2009 tentang Pelayanan Publik, terbagai atas: pertama, tindakan administratif pemerintah yang diwajibkan oleh negara dan diatur dalam peraturan perundang-undangan, yang meliputi perizinan dan non perizinan. Kedua, tindakan administratif oleh instansi non pemerintah yang diwajibkan oleh negara dan peraturan perundang-undangan berdasarkan perjanjian dengan penerima layanan, yang meliputi pemberian dokumen non perizinan. Hal ini mendasarkan bahwa perizinan adalah perbuatan pemerintah yang bersegi satu.

\section{Perizinan dan Good Governance}

Sejalan dengan dinamika masyarakat, tugas pemerintah juga berkembang tidak saja mengatur dan mengurus yang melahirkan instrument tradisional seperti ketentuan memerintah dan melarang, namun juga munculnya instrumen-instrumen lainnya seperti subsidi, izin, beschikking, termasuk sanksi administrasi. Izin sebagai bagian dari sejumlah instrumen baru, adalah yang paling banyak digunakan dalam hukum administrasi. ${ }^{7}$ Sulit untuk mendefinisikan pengertian izin, mengingat ada banyak sisi yang dapat dipakai sebagai landasan. Hal ini sejalan dengan pendapat van der Pot " het is uiterst moelijk voor begrip vergunning een definitie te vinden". ${ }^{8}$ Tanpa disadari, sering kita mempersamakan antara izin sebagai genus dengan macam-macam izin itu sendiri. Dalam arti sempit, izin menekankan pada suatu kondisi yang dilarang, kecuali diperkenankan, dengan syarat ada pemberian batas bagi tiap kasus. Oleh karena itu, penolakan izin terjadi hanya jika kriteria yang digariskan penguasa tidak terpenuhi. ${ }^{9}$ Izin adalah suatu keputusan administrasi negara yang memperkenankan suatu perbuatan yang pada umumnya dilarang dan bersifat konkrit. ${ }^{10}$

Izin sebagai perbuatan pemerintah bersegi satu, mempunyai fungsi penertib dan fungsi pengatur. Fungsi penertib dimaksudkan untuk adanya ketertiban kehidupan aktivitas masyarakat, seperti izin usaha, bangunan. Sementara, fungsi pengatur dimaksudkan agar pelaksanaan izin tidak menyimpang. Konsep yang ada pada sebuah izin, baik itu dispensasi, yaitu tindakan pemerintahan yang menyebabkan sesuatu peraturan undang-undang menjadi tidak berlaku, ${ }^{12}$ maupun lisensi sebagai izin yang memberikan hak untuk menyelenggarakan suatu perusahaan. Dalam sebuah dispensasi, kebijakan yang diambil pemerintah termasuk istimewa, mengingat bahwa pada dasarnya setiap aturan dibuat itu bukan untuk disimpangi. Namun dengan adanya dispensasi, kondisi bisa berubah sebaliknya, dan secara hukum tidak termasuk sebuah pelanggaran. Mengenai lisensi, fungsi mengatur dari sebuah izin nampak kental di sini, mengingat lisensi yang jug dapat dikategorikan sebagai betuk pengawasan pemerintah agar tindakan masyarakat tidak menyimpang. ${ }^{3}$ Sebagai missal di sini dapat digambarkan bagaimana seseorang tanpa lisensi dia melakukan aktivitas usaha, sangat mungkin terjadi bahwa usaha yang dijalankan adalah bertentangan dengan hukum, kepentingan umum bahkan bertentangan dengan tujuan negara. Contohnya, pengusaha bioskop yang menutar film tanpa adannya sensor terlebih dahulu. Sensor inilah sebagai syarat yang harus dipenuhi oleh penerima lisensi. Dalam hal ini, selaku pemegang kekuasaan, maka pemerintah berwenang untuk mencabut sebuah izin. Jenis izin yang lain adalah konsesi, sebagai sebuah

7. N.M. Spelt, J.B.M. ten Berge, 1991, Pengantar Hukum Perizinan, (penyunting) Philipus M. Hadjon, Utrecht, hlm. $1-2$.

8. Ridwan, HR, 2003, Hukum Administrasi Negara, Yogyakarta, UII Press, hlm. 151.

9. N.M. Spelt, J.B.M. ten Berge, Op. cit., hlm. 5.

10. Juniarso Ridwan, Achmad Sodik Sudrajat, 2012, Hukum Administrasi Negara dan Kebijakan Pelayanan Publik, 11. Bandung, Nuansa, hlm. 90.

12. Adrian Sutedi, 2015, Hukum Perizinan dalam Sektor Pelayanan Publik, Jakarta, Sinar Grafika, hlm. 195.

W.F. Prins, 1982, Pengantar Ilmu Hukum Administrasi Negara, Jakarta, Paramita, hlm. 72.

13. Suwari Akhmaddian, "Pengaruh Reformasi Birokrasi Terhadap Perizinan Penanaman Modal Di Daerah (Studi Kasus Di Pemerintahan Kota Bekasi)", Jurnal Dinamika Hukum, Vol. 12, No.3, September 2012, hlm. 464-478. 
izin berkait dengan pekerjaan besar, misalnya penambangan batubara, di sini nampak adanya kepentingan umum yang besar yang sebenarnya adalah tugas pemerintah namun diserahkan kepada masyarakat melalui pemenihan persyaratan.${ }^{14}$ Ketidakjelian memahami konsesi, banyak orang terkecoh bahwa konsesi masuk dalam hukum privat. Untuk itu maka perlu adanya pemahaman yang mendalam, bahwa keberadan sejumlah syarat yang harus dipenuhi warga masyarakat yang akan mengelola sebuah kegiatan besar menggantikan peran pemerintah, tidak lain dimaksudkan demi pemenuhan kepentingan umum, sehingg konsesi adalah termasuk bidang hukum publik. Hal ini nampak pada saat pemerintah melakukan penolakan permohonan konsesi, karena hanya pemerintahlah yang dapat memberikan penolakan. Sangat tidak mungkin warga masyarakat memberikan penolakan atas sikap pemerintah, karena dalam hukum publik disadari bahwa posisi pemerintah di atas warga negara.

Perizinan yang diberikan oleh Pemerintah membawa dampak bagi warga negara, baik dampak positif maupun dapak negatif. Dampak positif timbul manakala bedasar izin itu terciptalah ketertiban, keteraturan dalam masyarakat sebagai pintu utama memasuki ruang kesejahteraan. Sedangkan dampak negatif dapat muncul dalam rangka upaya pemenuhan persyaratan untuk memperoleh izin tersebut. Sebagai contoh dapat diilustrasikan bahwa pada saat seseorang akan mengajukan izin mendirikan bangunan, salah satu syarat vital adalah adanya izin dari tetangga. Hal ini dapat mengakibatkan pemalsuan dan manipulasi data guna memperoleh sebuah izin. Untuk menghindari penyalhgunaan sebuah izin, maka sebagaimana diatur dalam Pasal 7 ayat (2) Undang-Undang Nomor 30 Tahun 2014 tentang Administrasi Pemerintahan, bahwa pejabat berkait dengan pengeluaran sebuah keputusan, memiliki kewajiban antara lain:

a. membuat Keputusan dan/atau Tindakan sesuai dengan kewenangannya;

b. mematuhi asas-asas umum pemerintahan yang baik (AUPB) dan sesuai dengan ketentuan peraturan perundang-undangan;

c. mematuhi persyaratan dan prosedur pembuatan Keputusan dan/ atau Tindakan;

d. mematuhi undang-undang ini dalam menggunkan diskresi;

e. memberikan bantuan Kedinasan kepada Badan dan/ atau Pejabat Pemerintahan yang meminta bantuan untuk melaksanakan penyelenggaran pemerintahan tertentu;

f. memberikan kesempatan kepada warga masyarakat untuk didengar pendapatnya sebelum membuat Keputusan dan/ atau Tindakan sesuai dengan ketentuan peraturan perundang-undangan;

g. memberikn kepada warga masyarakat yang berkaitan dengan Keputusan dan/ atau Tindakan yang menimbulkan kerugian paling lama 10 (sepuluh) hari kerja terhitung sejak Keputusan dan/ atau Tindakan ditetapkan dan/ atau dilakukan;

h. menyusun standar operasional prosedur pembuatan Keputusan dan/ atau Tindakan;

i. memeriksa dan meneliti dokumen Administrasi Pemerintahan kepada warga masyarakat, kecuali ditentukan lain oleh undang-undang;

j. menerbitkan Keputusan terhadap permohonan warga masyarakat, sesuai dengan hal-hal yang diputuskan dalam keberatan/banding;

k. melaksanakan Keputusan dan/ atau Tindakan yang sah atau dibatalkan oleh Pengadilan, pejabat yang bersagkutan, atau Atasan Pejabat;

1. mematuhi putusan Pengadilan yang telah berkekuatan hukum tetap.

Untuk dapat menjalan ketentuan tersebut di atas secara efektif, maka sebagai bagian dari upaya reformasi birokrasi, pemerintah membuat Undang-Undang Nomor 5 tahun 2014 tentang Aparatur Sipil Negara dan disahkan pada 15 Januari 2014, yang mana salah satu tugas yang harus dijalankan oleh Aparatur Sipil Negara adalah memberikan pelayanan publik sebagaimana disebutkan dalam Pasal 10 yang harus diselaraskan dengan asas-asas umum

14. Ridwan, HR, Op. cit., hlm. 151. 
pemerintahan yang baik (AUPB).

Inilah salah satu pintu masuk bagi terwujudnya good governance, mengingat bahwa indikator adanya good governance sebagaimana disampaikan oleh United Nations Development Programme (UNDP) meliputi : participation, rule of law, transparency, responsiveness, consensus orientation, equity, effectiveness and efficiency, accountability, trategic vision. Sementara oleh Ganie-Rochman, dikembangkan 4 (empat) prinsip yang meliputi akuntabilitas, rule of law, informasi, dan transparansi. ${ }^{16}$

Pemberian perizinan yang baik menjadi mutlak adanya jika hal tersebut dianggap sebagai langkah menuju good governance, mengingat bahwa sekarang bukan lagi saatnya pejabat adalah pihak yang harus dilayani namun justru yang harus melayani masyarakat secara baik dan memuaskan. Setidaknya ada 3 urgensi reformasi birokrasi publik yang berdasarkan prinsip good governance ${ }^{17}$ yakni: a) perbaikan kerja pelayanan publik untuk mengurangi pengeluaran, b) Pelayanan publik sebagai ranah ketiga unsur governance yang paling intensif melakukan interaksi, dan, c) nilainilai good governance patutnya diaplikasikan dengan pemahaman sistem yang sederhana mealui pelayanan publik. Dengan demikian, perizinan yang baik merupakan satu kesatuan yang tidak terpisahkan dalam mewujudkan good governance.

Dalam implementasi peraturan di bidang perizinan yang mengarah pada terbangunnya good governance, pelaksana pelayanan publik di bidang perizinan menjadi sorotan utama yang mana mereka adalah pihak yang berhadapan langsung dengan warga masyarakat penerima layanan. Untuk itu, maka integritas berupa kejujuran, objektivitas dan standar kesantunan serta pertanggungjawaban penggunaan dana dan sumber daya publik menjadi sangat diperlukan.

\section{Upaya Optimalisasi Pelayanan Publik di Bidang Perizinan}

Berlakunya Undang-Undang Nomor 25 Tahun 2009 tentang Pelayanan Publik dan disertai Peraturan Pemerintah Nomor 96 Tahun 2012 tentang Pelaksanaan UndangUndang Nomor 25 Tahun 2009 tentang Pelayanan Publik, membawa konsekuensi logis bahwa pelayanan publik berupa perizinan yang diberikan kepada warga masyarakat selaku pemohon, harus dapat secara optimal memberikan rasa bahagia. Hal umum yang banyak dikeluhkan oleh warga masyarakat adalah berkait dengan proses yang berbelit sehingga berakibat waktu yang lama serta biaya yang tinggi.

Untuk bisa mengurai kerumitan dalam proses pemberian izin, keterbukaan menjadi hal yang sangat diperlukan. Keterbukaan di sini harus dipandang secara luas, yaitu baik keterbukaan berkait dengan informasi prosedur perolehan izin yang disampaikan kepada masyarakat, maupun keterbukaan dari para birokrat untuk menerima masukan, kritik, saran demi terbangunnya sebuah system pemberian perizinan yang baik dan tidak merugikan masyarakat. Hal ini sejalan dengan dengan konsep keterbukaan yang disampaikan oleh Adam Tomkins, ${ }^{18}$ yaitu: a) terbuka akses kepada dokumen, b) pengetahuan tentang siapa yang membuat keputusan dan bagaimana keputusan tertentu dibuat, c) komprehensif dan aksebilitas dalam kerangka kerja, struktur dan prosedur pembuatan keputusan, d) tersedianya ruang konsultasi, e) tugas untuk memberi alasan. Upaya yang ditempuh harus secara seimbang meliputi 2 (dua) bidang, yaitu dari sisi pelaksananya dan dari sisi aturannya. ${ }^{19}$

Berkait dengan birokrat selaku

15. Lembaga Administrasi Negara, 2000, Akuntabilitas dan Good Governance, modul 1 dari 5 Modul Sosialisasi Sistem Akuntabilitas Kinerja Instansi Pemerintah, Jakarta, Lembaga Administrasi Negara, hlm. 7.

16. Syakrani Syahriani, 2009, Implementasi Otonomi Daerah dalam Perspektif Good Governance, Yogyakarta, Pustaka Pelajar, hlm. 132.

17. Tedi Sudrajat, "Perwujudan Good Governance Melalui Format Reformasi Birokrasi Publik Dalam Perspektif Hukum Administrasi Negara", Jurnal Dinamika Hukum, Vol. 9, No. 2, 2009, hlm. 118-125.

18. Adam Tomkins, Transparency and the Emergence of a European Administrative Law, sebagaimana dikutip oleh Hasyim Asy'ary, "Korupsi Di Daerah dan Penguatan Kontrol Masyarakat”, Jurnal Masalah-Masalah Hukum, Jilid 42, No.1, Januari 2013, hlm. 36.

19. Agung Priyono, "Pelayanan Satu Atap Sebagai Strategi Pelayanan Prima Di Era Otonomi Daerah", Jurnal Spirit Publik, Vol. 2, No.2, Oktober 2006, hlm. 67-74 
pelaksana pelayanan publik di bidang perizinan, harus dapat mendudukkan dirinya dalam berbagai peran yang penting. Untuk lebih jelas, bhwa Pelaksana pelayanan publik, sebagaimana diatur dalam Undang-Undang Nomor 25 Tahun 2009, terdiri dari pejabat, pegawai, petugas, dan setiap orang yang bekerja di dalam organisasi penyelenggara yang bertugas melaksanakan tindakan atau serangkaian tindakan pelayanan publik. Adapun pilihan peranan yang dapat layak adalah, a) sebagai modernisator, artinya pelaksana harus mampu berinovasi melakukan suatu perubahan system, cara maupun bentuk demi hasil kerja yang lebih baik. b) Sebagai katalisator, bahwa pelaksana mampu bertindak sebagai penghubung antara masyarakat dengan pemerintah berkaitan dengan pemenuhan kebutuhan masyarakat soal perizinan. Di sini diharapkan komunikasi dua arah akan terjalin baik sehingga mampu menghasilkan karya yang baik pula. c) Sebagai dinamisator, maka pelaksana harus mampu menciptakan situasi dinamis dalam masyarakat yang diharapkan mampu membawa konsep pelayanan publik yang memberikan rasa nyaman pada masyarakat. d) Sebagai stabilisator, yang berarti pelaksana mampu menciptakan situasi keamanan pada masyarakat, dengan menekan gejolak yang mungkin timbul atas ketidakpuasan masyarakat. Hal ini hanya dapat dilakukan dengan pemberian layanan publik yang baik. e) Sebagai motivator, dalam hal ini pelaksana harus mampu menjadi teladan karena mampu memberikan layanan berlandaskan keikhlasan pengabdian. ${ }^{20}$ Dalam sisi ini, kekuatan moral yang mendorong pelaksana menjalankan perannya tidak dapat diabaikan. Tanpa semangat dan usaha maksimal, maka sebagus apapun aturan yang dibuat tidak akan berpengaruh. Tentang kesadaran moral, Lawrence Kohlberg ${ }^{21}$ membagi jenjang kesadaran moral menjadi 3 (tiga) tahapan besar, yaitu: moralitas pra-konvensional, moralitas konvensional dan moralitas purna konvensional, di mana tiap tahapan masih terbagi lagi dalam 2 (dua) jenjang.

Moralitas pra-konvensional yaitu moralitas yang mengandalkan kalkulasi untung rugi dalam hukuman, dan sering disebut moralitas kekanak-kanakan. Tahapan ini terbagi menjadi 2 (dua) jenjang, yaitu: pertama, ketaatan pada aturan hukum bukan rela dan sadar bahwa kesepakatankesepakatan dimaksud benar dan baik adanya, tapi karena takut mendapat sanksi. Sebagai contoh, seorang pegawai pulang lebih awal dari biasanya karena hari itu pimpinan sedang tidak berada di kantor. Dia melakukan itu karena yakin bahwa pimpinan tidak mengetahui dan sanksi tidak akan diberikan. Sementara sesuai degan aturan, bahwa pegawai tidak boleh pulang sebelum waktunya.

Kedua, bahwa tindakan moral seseorang sudah lebih rasional walaupun masih kekanak-kanakan. Motivasi dalam tindakan moral adalah untuk mencapai kenikmatan sebanyak-banyaknya dan mengurangi kesakitan sedapat-dapatnya, di mana tindakan moral seseorang hanya sebagai alat untuk mencapai tujuan. Ilustrasi diberikan, misalnya seorang birokrat yang mengetahui bahwa dalam proses penerimaan karyawan baru telah terjadi manipulasi data, sehingga beberapa pelamar "titipan" yang awalnya tidak masuk kategori yang akan diterima, dengan adanya perbuatan itu menjadi calon yang akan diterima sebagai karyawan baru. Sekalipun dia mengetahui, namun dengan model pendekatanannya kepada sang pimpinan menyampaikan penyimpangan yang terjadi dan berharap dia akan mendapat promosi jabatan, maka dia menutup rapat-rapat kepada fihak lain berkait tindakan tersebut, dan melakukan nego dengan pimpinan.

Moralitas konvensional yaitu karena cakrawala seseorang sudah lebih luas maka dia mulai memperhitungkan orang lain dan berusaha agar tidak melakukan apa yang dilarang. Moralitas konvensional ini terdiri dari dari 2(dua) jenjang, sehingga masuk

\footnotetext{
20. Peter Al Blau \& Charles H. Page, 1956, Bureucracy in Modern Society, sebagaimana dikutip oleh Safri Nugraha, dkk, 2005, Hukum Administrasi Negara, Jakarta, Fakultas Hukum Universitas Indonesia, hlm. 202-204. Periksa juga Bintoro Tjokroamidjojo, 1986, Pengantar Administrasi Pembangunan, Jakarta, LP3ES, hlm. 71-73.

21. Bernard L. Tanya, Yoan N. Simanjuntak dan Markus Y. Hage, 2010, Teori Hukum- Strategi Tertib Manusia Lintas Ruang dan Generasi, Yogyakarta, Genta Publishing, hlm. 35-39.
} 
kategori jenjang ketiga dan keempat. Pada jenjang ketiga, bahwa masalah benar dan baik ditentukan oleh orang lain atau harapan kelompoknya. Permasalahan relasi profesionalitas antara individu dengan yang lain disini juga bergantung pada budaya etnik yang berkembang. ${ }^{22}$ Dicontohkan di sini, bahwa seeorang tidak melakukan korupsi bukan karena takut dihukum, namum karena keluarganya melarang melakukan korupsi mengingat korupsi adalah melanggar hukum. Namun akan sulit jika budaya korupsi itu telah menggurita di kantornya, sehingga harus mengambil sikap, apakah tetap mematuhi nasihat keluarganya dengan tidak korupsi namun dengan konsekuensi bahwa ia akan tersingkir dari teman-teman di kantor. Jadi di sini akan diuji tentang loyalitas kepada keluarga atau memilih loyalitas pada temanteman sekantor yang melakukan tindakan negatif. Selanjutnya pada jejang keempat, berkait dengan contoh di atas, pada saat pegawai tersebut memilih untuk loyal kepada keluarga, dengan tidak melakukan korupsi, hal ini lebih didasarkan bahwa setiap pegawai itu harus memenuhi kewajiban hukum yang berlaku umum. Sekalipun disadari, bahwa pilihan itu mengandung risiko dijauhi oleh teman-teman sekantor.

Moralitas purna konvensional yaitu moralitas yang bersifat universal, yang terdiri dari jenjang kelima dan keenam. Pada jenjang kelima, orang menyadari bahwa hukumhukum yang ada sebenarnya tidak lain dari kesepakatan-kesepakatan. Di sini karena dasarnya adalah kesepakatn, maka sangat mungkin jika hukum itu sudah tidak lagi memberikan rasa nyaman pada masyarakat, maka atas kesepakatan masyarakat dapat mengubah hukum tersebut dengan hukum yang baru. Keenam, bahwa perkembangan pemikiran moral seseorang telah mencapai puncaknya. Seseorang akan bertindak bukan lagi karena takut pada orang lain atau takut jika posisinya akan tergeser, namun lebih pada tegaknya harkat dan martabat seluruh umat manusia, sekalipun mungkin banyak orang yang akan mencibir atas tindakannya tersebut. Namun, moralitas mereka bukan irasional tapi moralitas yang melampaui akal (transrasional).

Sisi aturan direalisasikan sesuai dengan ketentuan dalam Peraturan Pemerintah Nomor 96 Tahun 2012 tentang Pelaksanaan Undang-Undang Nomor 25 Tahun 2009 tentang Pelayanan Publik, yaitu dengan BAB III Pasal 11 tentang Sistem Pelayanan Terpadu. Sistem Pelayanan Terpadu dimaksud terbagi menjadi 2 (dua), yaitu (a)Sistem Pelayanan Terpadu Satu Pintu; dan (b)Sistem Pelayanan Terpadu Satu Atap. Adapun tujuan diselenggarakannya system pelayanan terpadu adalah: (1)memberikan perlindungan dan kepastian hukum kepada Masyarakat; (2)mendekatkan pelayanan kepada Masyarakat; (3)memperpendek proses pelayanan; (4)mewujudkan proses pelayanan yang cepat, mudah, murah, t r a n s a r a n, pasti, d a n terjangkau;(5)memberikan akses yang lebih luas kepada Masyarakat untuk memperoleh pelayanan.

Tidak berhenti sampai pada tahapan sistem pelayanan terpadu, baik Sistem Pelayanan Terpadu Satu Pintu maupun Sistem Pelayanan Terpadu Satu Atap, namun masih perlu juga sarana pelengkap berupa aspek pelayanan prima yang harus dilaksanakan oleh pelaksana. ${ }^{23}$ Adapun aspek-aspek yang terdapat dalam pelayanan prima, sebagai upaya pemerintah memberikan layanan yag baik dan memuaskan masyarakat, sebagaimana diatur dalam Peraturan Menteri Pendayagunaan Aparatur Negara dan Reformasi Birokrasi Nomor 38 Tahun 2012 Tetang Pedoman Penilaian Kinerja Unit, meliputi pelayanan yang cepat, tepat, murah, aman, berkeadilan, dan akuntabel.

\section{Simpulan}

Untuk memberikan kepuasan kepada masyarakat di bidang perizinan, model

22.Aldi Frinaldi dan Muhammad Ali Embi, "Pengaruh Budaya Kerja Etnik Terhadap Budaya Kerja Keberanian dan

Kearifan PNS Dalam Pelayanan Publik Yang Prima (Studi Pada Pemerintah Kabupaten Pasaman Barat)",

Proceeding Simposium Nasional Otonomi Daerah 2011, Serang, Laboratorium Administrasi Negara FISIP Untirta, 24-26 Mei 2011.

23.Jawoto Sih Setyono dan Muhammad Muktiali, “Analisis Pengembangan Pelayanan Terpadu Satu Pintu Sesuai Dengan Karakteristik Perkembangan Kota Semarang”, Jurnal Riptek, Vol. 3, No. 1, 2009, hlm. 13-23. 
pelayanan terpadu baik itu Pelayanan Terpadu Satu Pintu maupun Pelayanan Terpadu Satu Atap merupakan piliha yang tepat, mengingat masyarakat dapat dimudahkan dalam pengurusan di bidang perizinan. Sistem Pelayanan Terpadu ini memungkinkan para birokrat menjalankan perannya baik sebagai modernisator dengan membuat sebuah system baru; katalisator untuk menghubungakan antara masyarakat dengan pemerintah; dinamisator yaitu menciptakan situasi dinamis dalam masyarakat; stabilisator dalam rangka untuk menekan gejolak ketidakpuasan masyarakat; dan sebagai motivator untuk memberikan teladan dalam pemberian layanan publik.

\section{Daftar Pustaka}

Agung Priyono, "Pelayanan Satu Atap Sebagai Strategi Pelayanan Prima Di Era Otonomi Daerah", Spirit Publik, Vol. 2, No.2, Oktober 2006.

Asy'ari Hasyim, "Korupsi Di Daerah dan Penguatan Kontrol Masyarakat", Jurnal Masalah-Masalah Hukum, Vol. 42 No. 1, Januari 2013.

Frinaldi Aldi dan Muhammad Ali Embi, "Pengaruh Budaya Kerja Etnik Terhadap Budaya Kerja Keberanian Dan Kearifan PNS Dalam Pelayanan Publik Yang Prima (Studi Pada Pemerintah Kabupaten Pasaman Barat)", Proceeding Simposium Nasional Otonomi Daerah 2011, Serang, Laboratorium Administrasi Negara FISIP Untirta.

Hartono Sunaryati dkk, 2003, Panduan Investigasi untuk Ombudsman Indonesia, Jakarta, Komisi Ombudsman Nasional.

HR Ridwan, 2003, Hukum Administrasi Negara, Yogyakarta, UII Press.

KabarMedan.com, 9 Oktober 2015, "mayoritas Pelayanan Publik SKPD Pemkab Sergai Masuk Zona Merah", t e r s e d i a d i w e b s i t e http://www.ombudsman.go.id/index.ph $\mathrm{p} / \mathrm{en} / \mathrm{beritaartikel/berita/2171-}$ ombudsma--mayoritas-pelayanapublik-skpd-pemkab-sergai-masukzona-merah.html, diakses pada tanggal
19 Oktober 2015.

Lembaga Administrasi Negara, 2000, Akuntabilitas dan Good Governance, Modul 1 dari 5 Modul Sosialisasi Sistem Akuntabilitas Kinerja Instansi Pemerintah, Jakarta, Lembaga Administrasi Negara.

Nugraha Safri dkk, 2005, Hukum Administrasi Negara, Jakarta, Fakultas Hukum Universitas Indonesia.

Nurtjahjo Hendra, Yustus Matrbongs, Diani Indah Rachmitasari, 2013, Memahami Maladministrasi, Jakarta, Ombudsman Republik Indonesia.

Ombudsman Republik Indonesia Bidang Pencegahan, 2013, "Kepatuhan Lembaga dalam Pelaksanaan UndangUndang 25 Tahun 2009 tentang Pelayanan Publik", tersedia di website http://koleksifotoombudsman.files.wor dpress.com/20, diakses pada tanggal 19 Oktober 2015.

Palopo Pos, 10 September 2015, "Hanya BPMPPT dan Bagian SIM Berpotensi Zona Hijau", tersedia di website http://www.ombudsman.go.id/index.ph $\mathrm{p} /$ beritaartikel/berita/2079-hanyabpmppt-dan-bagian-sim-berpotensizona-hijau.html, diakses pada 19 Oktober 2015.

Prins W.F., 1982, Pengantar Ilmu Hukum Administrasi Negara, Jakarta, Paxcramita.

Ridwan Juniarso, Achmad Sodik Sudrajat, 2012, Hukum Administrasi Negara dan Kebijakan Pelayanan Publik, Bandung, Nuansa.

Spelt N.M., J.B.M. ten Berge, 1991, Pengantar Hukum Perizinan, (penyunting) Philipus M. Hadjon, Utrecht.

Sutedi Adrian, 2015, Hukum Perizinan dalam Sektor Pelayanan Publik, Jakarta, Sinar Grafika.

Setyono Jawoto Sih dan Muhammad Muktiali, "Analisis Pengembangan Pelayanan Terpadu Satu Pintu Sesuai Dengan Karakteristik Perkembangan Kota Semarang”, Jurnal Riptek, Vol. 3. No. 1, 2009.

Sudrajat Tedi, "Perwujudan Good Governance Melalui Format Reformasi 
Birokrasi Publik Dalam Perspektif Hukum Administrasi Negara", Jurnal Dinamika Hukum FH Unsoed, Vol.9, No.2, 2009.

Suwari Akhmaddian, "Pengaruh Reformasi Birokrasi Terhadap Perizinan Penanaman Modal Di Daerah (Studi Kasus Di Pemerintahan Kota Bekasi)", Jurnal Dinamika Hukum, Vol. 12 No.3, September 2012.

Syahriani Syakrani, 2009, Implementasi Otonomi Daerah dalam Perspektif Good Governance, Yogyakarta, Pustaka Pelajar.

Suara Merdeka, Sabtu 17 Oktober 2015, hlm. 28.

Tanya Bernard L., Yoan N. Simanjuntak dan Markus Y. Hage, 2010, Teori HukumStrategi Tertib Manusia Lintas Ruang dan Generasi, Yogyakarta: Genta Publishing.

Tjokroamidjojo, Bintoro, 1986, Pengantar Administrasi Pembangunan, Jakarta, LP3ES.

Undang-Undang Nomor 25 Tahun 2009 tentang Pelayanan Publik.

Undang-Undang Nomor 30 Tahun 2014 tentang Administrasi Pemerintahan.

Undang-Undang Nomor 39 Tahun 1999 tentang Hak Asasi Manusia.

Undang-Undang Nomor 5 Tahun 2014 tentang Aparatur Sipil Negara.

Peraturan Pemerintah Nomor 96 Tahun 2012 tentang Pelaksanaan Undang-Undang Nomor 25 Tahun 2009 tentang Pelayanan Publik.

Peraturan Menteri Pendayagunaan Aparatur Negara dan Reformasi Birokrasi Nomor 38 Tahun 2012 Tetang Pedoman Penilaian Kinerja Unit. 